\title{
Relation between the germination and infection ratio on Sida hermaphrodita L. Rusby seeds under hot water treatment
}

\author{
Kurucz, E., Szarvas, P., Fári, M. G. \\ Debreceni Egyetem Agrár és Gazdálkodástudományok Centruma \\ Kertészeti Intézet Növény Biotechnológiai nem önálló Tanszék, \\ Debrecen Böszörményi út 138
}

Corresponding author e-mail era.kurucz@gmail.com

\begin{abstract}
Summary: Sida hermephrodita or virginia mallow is a perspective perennial herb in the Malvaceae family able to yield a biomass crop through between ten and twenty years. Additionally, the plants have a lot of uses and benefits for instance it can use it as a fodder crop, honey crop, ornamental plant in public gardens. It has favorable features like fast growing and resistance against the disease and climatic fluctuations, etc. Sida is in base stage of domestication therefore has a serious disadvantage the low and slow germination as a big part of wild plants. Due to the expressly low germination percent the need of seed showing of driller is should tenfold, 200 thousand seed/acre instead of 10-20 thousand what is not available and expensive Therefore practical purposes of our research of seed physiology was to increase the seed germination percent in a disposable ,basically wild Sida population.

We examined two factors relating to seed germination percent and seed germination power during our research: the influence of hot water treatment and the effect of exogenus or endogenus infection of seed. However, in our germination tests, utilizing scarified seeds with hot water $\left(65,80\right.$ and $\left.95{ }^{\circ} \mathrm{C}\right), 29,33$ to $46 \%$ germinated of the seeds collected from the population of S. hermaphrodita in Debrecen. The average germination for all season was 5-10\% wihitout treatment and rised using hot water up to almost 50\%. When physically scarified used, the oldest seeds showed the best germination (46\%) after the hot water operation in spite of the previus studys (Spooner 1985; Chudik et al. 2010; Doli ski R. 2009.). We discovered that there are a distinguished close relationship between the seeds collecting time and the infection, as well as germination percentage. Thus, 2009 season was the most favourable in case of contamination (control:17,33 and $80{ }^{\circ} \mathrm{C}$ treatment:0\%) as well as germination percent. It could be concluded that, the best season for our findings was 2009 due to autumn harvest of Sida seeds. In our oppinion, the autumn harvesting should be the best time to overcome the problem of the low germination and high infection percentage.
\end{abstract}

Keywords: climate change; ornamentals; Wild sage; colour versions; preservation

\section{Introduction}

It is well known that, second generation energy plants (or perennial forage plants) are considered the future of bioenergy and are subject to intensive study for this reason. Compared with plants of the first generation, annual bearing fruits of the caryopsis type, they produce more energy at significantly less input and have a more favorable greenhouse gases (GHG) emission balance (Sanderson and Adler 2008). Among the currently plants grown for energy biomass, the Virginia mallow, willow, miscanthus, and switchgrass have a good chance of development, assuming that their profitability will be higher than in the case of plants grown for consumption (Pszczótkowska et al. 2012).

Our research program is focused on perennial mallow species which are not only ornamentals but at the same time they are producing large biomass as potential energy plants. Sida hermaphrodita L. Rusby, American virginian mallow or
Sida has been imported to Europe during the 1930-es (USSR, Ukrain, Poland) as a potential fiber plant. It has been studied as a potential biomass species in Poland from the 1950es and in Hungary from the 1970-es (by Zoltán Kováts). Commercial varieties of Sida $h$. have not been produced, although it may have serious economic impact in the future as a biomass plant. It could be also used in animal food and even as a vegetable for human consumption, honey plant, pulp, or phytoremediation plant. On the basis of the previous benefits, it is worth to mention that, Sida can be use as an excellent starting material for a complex breeding program in order to improve the germination rate (Kurucz et al. 2012).

The Sida hermaphrodita(Virginia mallow) is a perennial plant originating from North America. The species has been known in Poland for over fifty years, which is when the Agricultural Academy of Lublin (presently the University of Life Sciences) launched studies on the possibility of its cultivation and use as fodder. It is a honey plant with a 
honey output of $110-315 \mathrm{~kg} \mathrm{ha}^{-1}$. These discrepancies can be connected with seasonal differences. Unfertilizable and degenerating ovules with normally formed embryo sacs are common among Malvaceae species, e.g. in Malvaviscus arboreus Cav., Kydia calycina, and Thespesia populnea (Pszczółkowska et al. 2012).

$S$. hermaphrodita is known in the literature as a plant with low seed germination potential. In Europe, many author have dealt with this problem because of possible industrial uses of this plant (Chudzik et al. 2010)). For this reason, in Europe this plant is reproduced mainly in a vegetative way from root cuts.. The one of the limiting factor of this method is that currently not be well known about the Sida $h$. seeds virology,phatology and pests background. By this means the plantig by cuttings could be unsafe from the viewe of human and of environment.The other hardship is the sesonallity of egetative breeding. It is a greatly weather-depending techology. (Kurucz et al.2012)

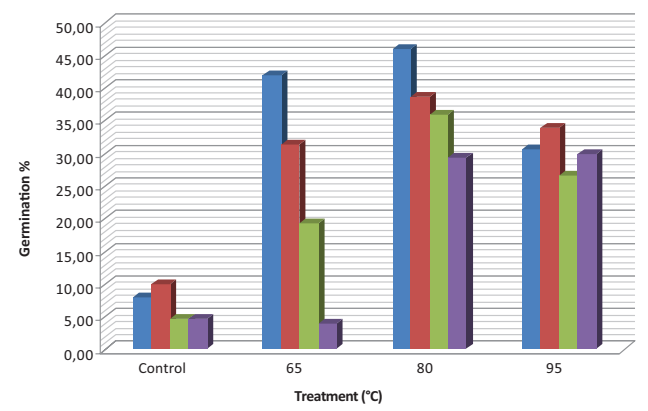

- 2009 Collection: autumn - 2011 Collection: spring II 2012 Collection: spring - 2013 Collection: spring

Figure 1: Influence of hot water treatment on germination( $\%$ ) of Sida $h$. Seeds

In general, there are many reasons which can responsible for the low germination of seeds.For example, in case of Sida was observed over $30 \%$ of the ovules remained in their juvenile stage at the time when pollen tubes reached the ovary. These ovules were probably unfertlizable, did not attract the pollen tubes and underwent degeneration before or during fruit development.(Chudzik et al. 2010). Under Polish conditions, other studies on the biology of flowering of $S$. hermaphroditain showed that as many as 95\% of seeds were set. From the results of some previous author, it could be concluded that, the main cause of low germination is the seeds dormancy (Baskin 2003; Barthodeiszky et al. 1980).

Seeds of the majority of plant taxa in the world except tropical rainforest and tropical semi-evergreen forest are dormant at maturity (Smith et al. 2004). Dormant seeds can be classified into one of five classes: physiological (low growth potential of the embryo); morphological (small undifferentiated or small differentiated, but underdeveloped, embryo); morphophysiological (underdeveloped, physiologically-dormant embryo); physical (water-impermeable palisade or palisade-like layer(s) of cells in seed (or fruit) coat); and combinational (waterimpermeable seed (or fruit) coat + physiologically dormant
Table 1: Influece of hot water treatment on germination (\%) and infection (\%) of Sida hermaphrodita L. RUSBY seeds

\begin{tabular}{|c|c|c|c|}
\hline Season & Treatment $\left({ }^{\circ} \mathrm{C}\right)$ & $\begin{array}{c}\text { Gerim- } \\
\text { nation \% }\end{array}$ & Infection \% \\
\hline \multirow{4}{*}{$\begin{array}{c}\text { 2009 Collection: } \\
\text { autumn }\end{array}$} & Control & 8,00 & 17,33 \\
\cline { 2 - 4 } & 65 & 42,00 & 0,07 \\
\cline { 2 - 4 } & 80 & 46,00 & 0,00 \\
\hline \multirow{3}{*}{$\begin{array}{c}2011 \\
\text { Collection:spring }\end{array}$} & 95 & 30,67 & 0,00 \\
\cline { 2 - 4 } & Control & 10,00 & 21,33 \\
\cline { 2 - 4 } & 65 & 31,33 & 10,00 \\
\hline \multirow{3}{*}{$\begin{array}{c}2012 \\
\text { Collection:spring }\end{array}$} & 90 & 38,67 & 5,33 \\
\cline { 2 - 4 } & Control & 34,00 & 4,00 \\
\cline { 2 - 4 } & 65 & 19,33 & 52,00 \\
\cline { 2 - 4 } & 90 & 36,00 & 18,67 \\
\hline \multirow{3}{*}{$\begin{array}{c}2013 \\
\text { Collection:spring }\end{array}$} & Control & 26,67 & 0,67 \\
\cline { 2 - 4 } & 65 & 4,67 & 36,00 \\
\cline { 2 - 4 } & 90 & 29,33 & 2,67 \\
\cline { 2 - 4 } & 95 & 30,00 & 0,00 \\
\hline
\end{tabular}

embryo] (Smith et al. 2004). Other authors divide seed dormancy into 7 class: undeveloped embryo, embryo is mechanicly inhibited by the seedcoat, water-impermeable coats (hard seed), gas-impermeable seed coats, endogen metabolism inhibitors, complex dormancy, secondary dormancy (Barthodeiszky et al. 1980).

Species with water-impermeable seed (or fruit) coats physical dormancy occur in some 15 plant families (Baskin 2003), including the Malvaceae. Barthodeiszky (1980) had called this phenomenon hard seed effect, and this kind of seeds was called hard seed. This impermeability of the coat is caused by the presence of one or more palisade layers of lignified malphigian cells (macrosclereids) tightly packed together and impregnated with water- repellant chemicals (Baskin et al. 2000). An anatomical structure in the impermeable layer(s) functions as the 'water gap', seven types of which have been described (Baskin et al., 2000). Species with water-impermeable seed (or fruit) coats physical dormancy - occur in the following plant families (Baskin 2003):

- Anacardiaceae

- Bixaceae

- Cannaceae

- Cistaceae

- Cochlospermaceae

- Convolvulaceae (including Cuscutaceae)

- Curcurbitaceae

- Dipterocarpaceae (subfamilies Montoideae and Pakaraimoideae, but not Dipterocarpoideae)

- Fabaceae (subfamilies Caesalpinioideae, Mimosoideae and Papilionoideae)

- Geraniaceae

- Malvaceae (including Bombacacaceae, Sterculiaceae, and Tiliaceae)

- Nelumbonaceae 
Table 2.: Analysis of variance tables Multiple Comparisons (Dependent Variable: germination \%)

\begin{tabular}{|c|c|c|c|c|c|c|}
\hline \multirow[t]{2}{*}{ (I) Treatment } & \multirow[t]{2}{*}{ (J) Treatment } & \multirow[t]{2}{*}{ Mean Difference (I-J) } & \multirow[t]{2}{*}{ Std. Error } & \multirow[t]{2}{*}{ Sig. } & \multicolumn{2}{|c|}{ 95\% Confidence Interval } \\
\hline & & & & & Lower Bound & Upper Bound \\
\hline \multirow[t]{3}{*}{0,00} & 65,00 & $-17,50000(*)$ & 4,14784 & 0,000 & $-25,8594$ & $-9,1406$ \\
\hline & 80,00 & $-30,83333(*)$ & 4,14784 & 0,000 & $-39,1927$ & $-22,4739$ \\
\hline & 95,00 & $-23,66667(*)$ & 4,14784 & 0,000 & $-32,0261$ & $-15,3073$ \\
\hline \multirow[t]{3}{*}{65,00} & 0,00 & $17,50000(*)$ & 4,14784 & 0,000 & 9,1406 & 25,8594 \\
\hline & 80,00 & $-13,33333(*)$ & 4,14784 & 0,002 & $-21,6927$ & $-4,9739$ \\
\hline & 95,00 & $-6,16667$ & 4,14784 & 0,144 & $-14,5261$ & 2,1927 \\
\hline \multirow[t]{3}{*}{80,00} & 00 & $30,83333(*)$ & 4,14784 & 0,000 & 22,4739 & 39,1927 \\
\hline & 65,00 & $13,33333(*)$ & 4,14784 & 0,002 & 4,9739 & 21,6927 \\
\hline & 95,00 & 7,16667 & 4,14784 & 0,091 & $-1,1927$ & 15,5261 \\
\hline \multirow[t]{3}{*}{95,00} & 0,00 & $23,66667(*)$ & 4,14784 & 0,000 & 15,3073 & 32,0261 \\
\hline & 65,00 & 6,16667 & 4,14784 & 0,144 & $-2,1927$ & 14,5261 \\
\hline & 80,00 & $-7,16667$ & 4,14784 & 0,091 & $-15,5261$ & 1,1927 \\
\hline
\end{tabular}

* The mean difference is significant at the .05 level. 0,00 means the ontrol

- Rhamnaceae

- Sapindaceae

- Sarcolaenaceae

However, Dolinski. (2009) have presented evidence that dormancy-break by heating and by chemically in Sida $h$. seeds. may occur through disruption of the seed coat in (a) region(s) other than the lens.

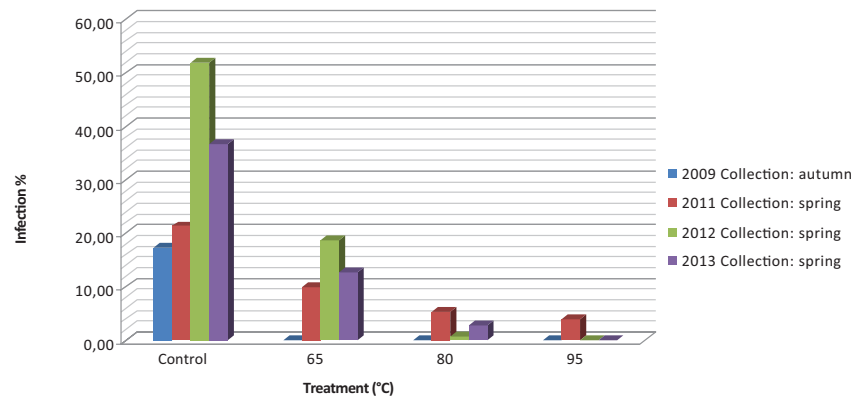

Figure 2: Influence of hot water treatment on infection (\%) of Sida $h$. Seeds

Immediately after the harvest, only $3 \%$ of control seeds sprouted, where as after the 6 months their germination increased to $14.5 \%$ to $35.5 \%$ after 1.5 years, with subsequent decrease (Dolinski 2009). Hard seeds of Virginia fanpetals stopped their dormancy due to hot water treatment. Fresh seeds had the best germination (73\%) after immersing into the boiling water; germination capacity decreased along with the water temperature decrease. Water at 70 to $80^{\circ} \mathrm{C}$ temperature had the most positive effects on very seasons seeds (Dolinski 2009). Spooner (1985) concluded that, the scarified seeds, 81 to $99 \%$ of the seeds collected from the 10 populations of $S$. hermaphrodita in Maryland and Ohio germinated, respectively. The average germination for all 10 populations was $92 \%$ (Spooner et al 1985). They collected the seeds in August and September. Whereas, the other studies did not mentioned the harvesting date. Boiling water has not damaged the germs of fresh seeds, but more and more seeds imbibed without germination in subsequent examination dates (Dolinski 2009). The previous studies revealed that seeds of some species of malvaceae family scarified using hot water or concentrated sulphuric acid could ave postive effect on seed germination percent (Dolinski 2009; Baskin et al. 2000). Even more, it have been stored for a long time with no fear of their fast loss of germination capacity (Dolinski 2009).

The aim of this investigation was to study the effect of hot water treatment and the influence date of seed collection with 4 seasons on $S$. hermaphodita seed germination percent and infection rate.

\section{Material and Methods}

\section{Seed collection}

Germination/ viability tests were conducted during February 2013 on seeds of Sida collected from experiental populations in Future Biomass Plants Garden of the Department, Agricultural Experimental Station of the Faculty of Agriculture, in different years, i.e., 2009, 2011, 2012 and 2013. The samples were collected from fresh harvested and manually threshed.

In 2009, seeds were collected in autumn. In the following seasons, we gathered the seeds in spring in order to ensure the low temperature impression which is considered necessary. Therefore, in the following seasons 2011, 2012 and 2013, the seeds were collected in spring time.

\section{Hot water treatment}

Seeds of each samples (except the contols) were immersed into water the following temperature and period :65 and $80^{\circ} \mathrm{C}$ for 2 minutes and $95^{\circ} \mathrm{C}$ for 30 seconds, nonscarified seeds constituted the control and then, part of seeds from every combination $(3 \times 50)$ were sown onto Petri dishes 
Table 3.: Analysis of variance tables Multiple Comparisons( Dependent Variable: Infection\%)

\begin{tabular}{|c|c|c|c|c|c|c|}
\hline \multirow[t]{2}{*}{ (I) Treatment } & \multirow[t]{2}{*}{ (J) Treatment } & \multirow[t]{2}{*}{ Mean Difference (I-J) } & \multirow[t]{2}{*}{ Std. Error } & \multirow[t]{2}{*}{ Sig. } & \multicolumn{2}{|c|}{$\mathbf{9 5 \%}$ Confidence Interval } \\
\hline & & & & & Lower Bound & Upper Bound \\
\hline \multirow[t]{3}{*}{0,00} & 65,00 & $21,00000(*)$ & 3,65649 & 0,000 & 13,6308 & 28,3692 \\
\hline & 80,00 & $29,33333(*)$ & 3,65649 & 0,000 & 21,9642 & 36,7025 \\
\hline & 95,00 & $30,50000(*)$ & 3,65649 & 0,000 & 23,1308 & 37,8692 \\
\hline \multirow[t]{3}{*}{65,00} & 0,00 & $-21,00000(*)$ & 3,65649 & 0,000 & $-28,3692$ & $-13,6308$ \\
\hline & 80,00 & $8,33333(*)$ & 3,65649 & 0,028 & ,9642 & 15,7025 \\
\hline & 95,00 & $9,50000(*)$ & 3,65649 & 0,013 & 2,1308 & 16,8692 \\
\hline \multirow[t]{3}{*}{80,00} & 0,00 & $-29,33333(*)$ & 3,65649 & 0,000 & $-36,7025$ & $-21,9642$ \\
\hline & 65,00 & $-8,33333(*)$ & 3,65649 & 0,028 & $-15,7025$ &,- 9642 \\
\hline & 95,00 & 1,16667 & 3,65649 & 0,751 & $-6,2025$ & 8,5358 \\
\hline \multirow[t]{3}{*}{95,00} & 0,00 & $-30,50000(*)$ & 3,65649 & 0,000 & $-37,8692$ & $-23,1308$ \\
\hline & 65,00 & $-9,50000(*)$ & 3,65649 & 0,013 & $-16,8692$ & $-2,1308$ \\
\hline & 80,00 & $-1,16667$ & 3,65649 & 0,751 & $-8,5358$ & 6,2025 \\
\hline
\end{tabular}

* The mean difference is significant at the .05 level .0,00 means the contol.

on wetted filter paper, while others stored for further studies. Seedling counts were performed at 3 and 6 days and total percent of germination and contamination were calculated for each treatment.

\section{Statistical analysis}

The research results were calculated by Windows Office Exel software and evaluated statistically by the analysis of variance using the SPSS 14.0. program.

\section{Results}

Effects of various temperatures of water and influence of differnt seasons for overcoming seed dormancy and the amount of contamination in seeds of Sida hermaphrodita (Malvaceae) are showed in Table 1. It could be noticed that dipping seeds into boiling water or incubating them broke dormancy in seeds of Sida hermaphrodita. In addition, the percent of contamination decreased along with the water temperature rise increase.

\section{Germination \%}

Sidas seeds without treatment only $4-5 \%$ of seeds sprouted, except the 2009 years seeds in whitch the germination percent was the best $10 \%$ in the control seeds. This effect is contrast the previous observations by Chudik et al. (2010) who find that the long storage period (more than 3 years) decrease Sida seeds germination percent.

The seeds of season 2009 had the best germination percent (46\%) after immersing into the boiling water; germination capacity decreasd along with the water temperature decreased. As Figure 1. shows water at $80^{\circ} \mathrm{C}$ temperature had the most positive effects in almost every seasons seeds. However in case of 2013 seeds germination was independent in the collecting season. There was not significant difference between the $80^{\circ} \mathrm{C}$ and the $95^{\circ} \mathrm{C}$ (Table 2.). Moreover, it could be mentioned that, they have a similar germination percent. Boiling water has not damaged the germs of fresh seeds, but some seeds imbibed without germination as mentioned before.

\section{Infection \%}

Table 1 clearly show that, the rate of infection is gradually decreased along the water temperature increase. It could be noticed in the bar chart (Fig. 2) the most contaminated season was season 2012 in which the contamination was $52 \%$ in the control. On the average opposite of the seeds of 2009 were $17.33 \%$ infected seeds the average of three replicates. The The statistics analyse (Table 3.) clearly shows the significant difference between the contol and the treated $\left(65^{\circ} \mathrm{C}, 80^{\circ} \mathrm{C}\right.$, $95^{\circ} \mathrm{C}$ ). samples meanwhile the differences between $80^{\circ} \mathrm{C}$ and $95^{\circ} \mathrm{C}$ is not significant because both treatments generate $0 \%$ infection. The infection ratio in the control seeds of all season fluctuates considerably, these discrepancies can be connected with seasonal and harvesting date differences.

\section{Conclusion}

Hard seeds are common phenomena in a number of species in the Malvaceae (Spooner 1985), including Sida spinosa L. have shown that water impermeability in Sida spinosa seeds is, partly, due to a compact layer of integumentary palisade cells. A similar layer of cells occurs in seeds of Sida hermaphrodita Hard seeds of Sida stopped their dormancy due to hot water treatment (Chudzik et al 2010).

Spooner et al. (1985) founded that the low germination percentages obtained apparently due to his failure to scarify the seeds. It should be added that the seeds was collected in autumn in 1985 study. 
However, in this work, germination tests utilizing scarified seeds germinated from 29,33 to $46 \%$ of the seeds collected from the population of $S$. hermaphrodita in Debrecen Agricultural Research Station. The average germination for all season was 4,67 -10\% wihitout treatment and hot water can rise it to almost $50 \%$. When physically scarified, the oldest seeds showed the best germination percent (46\%) after imerging into hot water.

This study revealed that Sida hermaphrodita seeds scarified using hot water has a positive effect on Sida $h$. seeds contaminaton. The highest percentage of contamination was observed in season of 2012. The infection ratio was reduced by $52 \%$ to $0 \%$ in certain cases due to hot treatment and the rate of infection is gradually decreased along the water temperature increase. The same effect was observed in all seasons. The most favorable temperature was the $95^{\circ} \mathrm{C}$ naturally, but if we take account the germination percent we should conclude from the data that the most effective water temperature was the $80^{\circ} \mathrm{C}$.

However, the germination potential of $S$. hermaphrodita seeds showed variability depending on the vegetative season . In many experiments the maximum number of germinating seeds was about $30-40 \%$. For this reason, in Europe this plant is reproduced mainly in a vegetative way (Chudik et al. 2010).

We had discovered that an apparent close relationship between the seeds collecting time and the infection - as well as germination percentage. Thus, 2009 season was the best in case of contamination as well as germination percent. It could be concluded that, the most favorable period of seed collecting for propagation is autumn, after the seed become mature.

From the investigations presented in this work, it could not be concluded clearly that the features observed during the investigated stage of Sida hermaphrodita seeds have physically or physiology dormancy, or both. Nonetheless, it should be cleard that how can we characterize and prevent the endogenous or exogenous seed infection. It should be underlined that the present study is the first in the series of studies in which we plan to undertake the problem of the embryology of this promising energetic species.

\section{Acknowledgement}

The present work has been supported by MOP-Biotech Ltd. (Nyíregyháza), and by the Károly Ereky Biotechnology Foundation (Debrecen).

\section{References}

Barthodeiszky A., Czimber Gy:: 1980: A magbiológia alapjai Baskin C.C. 2003: Breaking physical dormancy in seeds focussing on the len s in: New Phytologist 158, 229-232

Baskin J. M. and Baskin C. C and Xiaojie Li 2000: Taxonomy, anatomy and evolution of physical dormancy in seeds, in: Plant Species Biology Volume 15, Issue 2, p 139-152

Baskin J. M. and Baskin C. C. 2003: When Breaking Seed Dormancy Is a Problem: Try a Move-along Experiment in:Native Plant Journal 4:(1) 17-21

Chudzik B., Szczuka E., Domaciuk M.and P. Danail 2010 : THE STRUCTURE OF THE OVULE of Sida hermaphrodita (L.) RUSBY after pollination ACTA AGROBOTANICA Vol. 63 (2): $3-11$

Doliński R. 2009: Influence of treatment with hot water, chemical scarification and storage time on germination of Virginia fanpetals (Sida hermaphrodita (L.) Rusby) seeds, Biuletyn Instytutu Hodowli i Aklimatyzacji Roślin 2009 No. 251 pp. 293-303

Kurucz E., Szarvas P., Fári M. G. 2012: Alternatives of the multiple use Of Virginia mallow in ACTA AGRARIA DEBRECENIENSIS Vol. 46,51-57

Pszczółkowska A., Romanowska-Duda Z., Pszczółkowskimieczysław W. Grzesik, and Wysokińska Z. (2012): Biomass Production of Selected Energy Plants: Economic Analysis and Logistic Strategies, Comparative Economic Research. Volume 15, Issue 3, Pages 77-103, ISSN (Online)

Sanderson M. A. and Adler P. R. (2008), Perennial Forages as Second Generation Bioenergy Crops, "International Journal of Molecular Sciences", 9: 768-788

Smith R., Dickie J., Linington S., Pritchard H. and Probert R. 2004:Seed Conservation: Turning Science into Practice ISBN 1842460528

Spooner D. M. 1985: Observations On The Distribution And Ecology Of Sida hermaphrodita (1.) RUSBY (malvaceae) 